\title{
The interplay between NLRs and autophagy in immunity and inflammation
}

\author{
Leticia A. M. Carneiro ${ }^{1 *}$ and Leonardo H. Travassos ${ }^{2 *}$ \\ 1 Department of Immunology, Federal University of Rio de Janeiro, Rio de Janeiro, Brazil \\ ${ }^{2}$ Institute of Biophysics Carlos Chagas Filho, Federal University of Rio de Janeiro, Rio de Janeiro, Brazil
}

\section{Edited by:}

Thomas A. Kufer, University of

Cologne, Germany

Reviewed by:

Ashley Mansell, Monash Institute of

Medical Research, Australia

Cheol-Heui Yun, Seoul National

University, South Korea

*Correspondence:

Leticia A. M. Carneiro, Department of

Immunology, Federal University of

Rio de Janeiro, Av. Carlos Chagas

Filho, 373 Bloco G/20 Andar Sala

G2-042 CCS-Ilha do Fundão, Rio de

Janeiro 21.941-902, Brazil

e-mail: leticiac@micro.ufrj.br ;

Leonardo H. Travassos, Institute of

Biophysics Carlos Chagas Filho,

Federal University of Rio de Janeiro,

Av. Carlos Chagas Filho, 373 Bloco

G/20 Andar Sala G2-042 CCS-Ilha do

Fundão, Rio de Janeiro 21.941-902,

Brazil

e-mail: leo.travassos@biof.ufri.br
Since they were first described as cytosolic sensors of microbial molecules a decade ago, the Nod-like receptors (NLRs) have been shown to have many different and important roles in various aspects of immune and inflammatory responses, ranging from antimicrobial mechanisms to control of adaptive responses. In this review, we focus on the interplay between NLRs and autophagy, an evolutionarily conserved mechanism that is crucial for homeostasis and has recently been shown to be involved in the protective response against infections. Furthermore, the association between mutations of NLRs as well as proteins that form the autophagic machinery and inflammatory diseases such as Crohn's disease highlight the importance of these proteins and their interactions in the regulation of inflammation.

Keywords: NLR proteins, autophagy, inflammasomes, inflammation, infection, Crohn's disease, innate immunity

\section{INTRODUCTION}

Homeostasis in multicellular organisms is dependent on the ability to detect and adapt to a myriad of environmental variations and insults, including exposure to microbes. Early detection of microbes is a crucial step in the defense strategy. Throughout evolution, the continuous interplay between multicellular organisms and microbes has led to the selection of sensors that allow early detection and initiation of the immune response against infections. This detection is based on the recognition of "microbial-associated molecular patterns" (MAMPs), which represent a signature of microbial origin, such as lipopolysaccharide (LPS), peptidoglycan (PG), flagellin, and nucleic acids from bacteria and viruses, or of "danger-associated molecular patterns" (DAMPs), which indicate the existence of cellular damage, such as extracellular ATP and HGMB1 by "pattern recognition molecules"(PRMs). Upon activation, PRMs trigger several protective responses that include the recruitment of phagocytic cells; secretion of chemokines, cytokines, and antimicrobial peptides; and priming of dendritic cells (DCs), engaging the adaptive immune system. Several families of PRMs have been described and include "Toll-like receptors" (TLRs), "RIG-I like receptors" (RLRs), "Clectin type like receptors" (CLR), and "Nod-like receptors" (NLRs). In addition to their role in innate and adaptive immune responses, all of them have been recently implicated in the control of autophagy, an adaptive cellular response to environmental and microbial-induced stress. In this review, we highlight the role of NLR signaling in the control of autophagy and vice versa, the mechanisms involved and implications for inflammatory diseases such as Crohn's disease (CD) and type 2 diabetes (T2D).

\section{NLR PROTEINS}

Soon after the discovery of the transmembrane TLRs, it became evident that additional sensors were necessary for the surveillance of the cytosol. More than a decade ago, the demonstration that a mammalian homolog of plant disease-resistance $(R)$ proteins called Nod 1 could detect the presence of intracellular Shigella flexneri and activate the transcription factor nuclear factor $\mathrm{\kappa B}$ (NF$\kappa \mathrm{B})$ in epithelial cells in vitro inaugurated the studies on the role of NLRs as innate immune intracellular sensors (1). Subsequent studies have now set the number of human NLRs at approximately 20 and indicated their involvement in detecting not only microbial components but also DAMPs such as ATP, mitochondrial DNA (mtDNA) and reactive oxygen species (ROS) (2).

Due to the lack of signal peptides or transmembrane domains in their amino acid sequences, NLRs are thought to be exclusively located inside the cell. Both plant and animal NLRs are signal-transduction ATPases with numerous domains (STAND) P-loop ATPases of the $\mathrm{AAA}^{+}$superfamily. The typical NLR protein contains the following domains: (a) a C-terminal leucine-rich repeat (LRR) domain, involved in sensing; (b) a central NATCH [Naip, CIITA, HET-E (plant het product involved in vegetative incompatibility)] and TP-1 (telomerase-associated protein 1 that mediates self-oligomerization and is essential for activation of NLRs); and (c) an N-terminal effector domain, responsible for 
protein-protein interactions with adapter molecules and signal transduction. Based on the nature of the $\mathrm{N}$-terminal domains, NLRs have been separated into the NLRC subfamily, containing a CARD domain (caspase activation and recruitment domain); the NLRP subfamily, containing a pyrin domain; and the NAIP subfamily, which includes three (BIRs) baculovirus inhibitors of the apoptosis protein repeat domain (3).

\section{Nod1 (NLRC1) AND Nod2 (NLRC2) ARE INTRACELLULAR PEPTIDOGLYCAN SENSORS}

Nod1 and Nod2 were the first NLRs identified as MAMP detectors when two concomitant studies demonstrated that Nod2 detects muramyl-dipeptide (MDP), a common motif found in Gram-negative and Gram-positive PG and a major component of adjuvants $(1,4-6)$. Nod1, in contrast, recognizes PG containing the minimal motif meso-diaminopimelic acid (DAP), an amino acid found in Gram-negative and some Grampositive bacteria, such as Listeria monocytogenes and Bacillus subtilis. The naturally occurring PG moieties sensed by human and mouse Nod1 are GlcNAc-MurNAc-L-Ala-D-Glu-meso-DAP (GM-triDAP) and GlcNAc-MurNAc-L-Ala-D-Glu-meso-DAP-DAla (GM-tetraDAP), respectively. After additional studies demonstrated that PG recognition by TLR2 was due to contaminants commonly found in PG preparations, it became clear that Nod1 and Nod2 are the only known PG sensors (2, 7-9). The NLR ligands/activators are summarized in Table 1.

Nod1 and Nod2 have been implicated in the detection of a vast array of microbial pathogens including bacteria, parasites, and viruses. A key role for Nod1 and Nod2 in the detection of bacterial infection has been demonstrated in Helicobacter pylori, Escherichia coli, Chlamydia spp., Campylobacter jejuni, Salmonella spp., Pseudomonas aeruginosa, S. flexneri, and L. monocytogenes, Mycobacterium tuberculosis, and Streptococcus pneumoniae (Table 1).

More recent studies have uncovered surprising data regarding microbial recognition by Nod1 and Nod2. Nod1-deficient mice are more susceptible to infection with Trypanosoma cruzi, the etiological agent of Chagas disease, apparently due to the lack of a robust nitric oxide production, suggesting that Nod1 may be involved in PG-independent microbial sensing given that T. cruzi does not express PG $(3,28)$.

Supporting a role for Nod 2 in the control of infections beyond bacterial/PG detection, Shaw et al. using a Toxoplasma gondii infection model, described a $\mathrm{T}$ cell intrinsic role in Nod2-deficient mice and a consequent Th1-defective immune response. In their experiments, the authors observed lower amounts of IL- 2 not only during infection with $T$. gondii but also following anti-CD28 ligation. Despite the novelty of these results, $\mathrm{T}$ cell activation in different models appears to be normal in Nod2-deficient mice $(75,76)$.

Nod2 has also been implicated in the immune response to viruses. In a recent study, Sabbah et al. demonstrated that Nod2 mediated the in vitro production of type I IFN in cells stimulated with single stranded RNA (ssRNA) or infected with various RNA viruses. These results support the observation, made in the same study, that Nod2-deficient mice are more susceptible to respiratory syncytial virus (RSV) (29).
Finally, both Nod1 and Nod2 have been implicated in inflammatory disorders because mutations in the genes that encode these proteins were shown to be related to the establishment of genetic inflammatory diseases. The first piece of evidence of a link between mutations in NOD2 and CD [an inflammatory bowel disease (IBD)] was provided by Hugot et al. which identified three single nucleotide polymorphisms (SNPs) in the IBD1 locus associated with increased risk for CD (77). One of these SNPs, Leu1007fs, is the most common Nod2 mutation associated with the disease and encodes a protein that is no longer able to sense MDP or localize to the plasma membrane as the normal protein does upon activation $(4,78)$.

\section{INFLAMMASOMES}

By definition, inflammasomes are multimeric protein complexes that comprise a "sensor NLR" and function as platforms for the activation of pro-caspase-1, resulting in the processing of IL- $1 \beta$ and IL-18 and their unconventional secretion $(6,79)$. Several inflammasomes have been described so far, and among them, the best studied are the ones that contain NLRP3 (formerly known as NALP3) or NLRC4 (formerly known as IPAF). Many NLRs, such as NLRP1, NLRP3, and NLRC4, use the adaptor protein apoptosisassociated speck-like protein containing a CARD (ASC) to recruit pro-caspase-1, but this does not apply to all inflammasomes.

\section{NLRP3 INFLAMMASOMES}

NLRP3 is mostly expressed in myeloid cells and is activated by a vast array of host-derived and exogenous agonists. One common feature of NLRP3 agonists seems to be a crystalline or polymeric structure associated with danger signals or cell death. For example, monosodium urate (MSU), calcium pyrophosphate dihydrate (CPPD) (41), cholesterol crystals (42), amyloid $\beta$ (80), fatty acids (47), and mtDNA (48) have all been reported to activate NLRP3. Microbial NLRP3 agonists have also been identified. NLRP3 senses bacteria, viruses, fungi, and parasites themselves or virulence factors such as pore-forming toxins. The list of pathogens detected by NLRP3 includes Staphylococcus aureus, L. monocytogenes, Klebsiella pneumoniae, Neisseria gonorrhoeae, E. coli, Porphyromonas gingivalis, S. flexneri, Chlamydia spp., the influenza A virus, Aspergillus, and more recently, Leishmania (Table 1).

\section{NLRC4 AND Naip5}

IPAF (also known as NLRC4) is present in the cytosol of myeloid cells, where it controls the activation of caspase- 1 and IL- $1 \beta$ processing in response to the presence of intracellular flagellin. NLRC4 directly binds to cytosolic flagellin, an event that promotes its oligomerization through the nucleotide-binding domain (NBD) and winged-helix domain (WHD) in the presence of adenosine diphosphate (ADP) (81). The importance of IPAF-dependent activation of caspase-1 has been highlighted in infection models in vitro using Salmonella typhimurium, S. flexneri, Legionella pneumophila, and $P$. aeruginosa $(66,70,74)$. In such experiments, IPAF-deficient macrophages were impaired in their ability to activate caspase- 1 and secrete IL-1 $\beta$ and IL-18. Macrophages from IPAF-deficient mice infected with $S$. typhimurium have also been shown to be more resistant to cell death. Indeed, activation of NLRC4 leads to rapid cell death, a feature that differentiates IPAF 
Table 1 | NLR proteins involved in autophagy and their activators.

\begin{tabular}{|c|c|c|}
\hline NLR protein & Activator & Reference \\
\hline \multirow[t]{11}{*}{ Nod1 (NLRC1) } & FK156 (d-lactyl-I-Ala- $\gamma$-Glu-meso-DAP) & Uehara et al. (10) and Magalhaes et al. (11) \\
\hline & FK565 (Heptanoly) & Uehara et al. (10) \\
\hline & iEDAP ( $\gamma$-d-Glu-meso-DAP) & Girardin et al. (159) and Chamaillard et al. (9) \\
\hline & TriDAP (I-Ala- $\gamma$-d-Glu-meso-DAP) & Girardin et al. (4) \\
\hline & L. pneumophila & Hasegawa et al. (13) \\
\hline & S. typhimurium & Hasegawa et al. (13) and Le Bourhis et al. (14) \\
\hline & H. pylori & Viala et al. (15) \\
\hline & Pseudomonas species & Travassos et al. (7) \\
\hline & Chlamydia species & $\begin{array}{l}\text { Kavathas et al. (16), Buchholz and Stephens (17), Welter-Stahl et al. } \\
\text { (18) and Opitz (19) }\end{array}$ \\
\hline & C. jejuni & Al-Sayeqh et al. (26) and Zilbauer et al. (27) \\
\hline & T. cruzi & Silva et al. (28) \\
\hline \multirow[t]{8}{*}{ Nod2 (NLRC2) } & Muramyldipeptide (MurNAc-I-Ala-d-isoGIn) & Girardin et al. (8) and Inohara et al. (5) \\
\hline & M-TriLys (Mur-NAc-I-Ala-d-Glu-Lys) & Girardin et al. (4) \\
\hline & Respiratory syncytial virus (RSV) & Sabbah et al. (29) \\
\hline & Bacillus species & Hasegawa et al. (13) \\
\hline & Lactobacillus species & Hasegawa et al. (13) \\
\hline & Corynebacterium xerosis & Hasegawa et al. (13) \\
\hline & E. coli & Hasegawa et al. (13) \\
\hline & Pseudomonas species & Hasegawa et al. (13) \\
\hline Nalp3 (NLRP3) & Muramyldipeptide (MurNAc-I-Ala-d-isoGln) & Martinon et al. (39) \\
\hline & Bacterial RNA & Kanneganti et al. (40) \\
\hline & Imidazoquinoline compounds & Kanneganti et al. (40) \\
\hline & MSU (monosodium urate) & Martinon et al. (41) \\
\hline & CPPD (calcium pyrophosphate dihydrate) & Martinon et al. (41) \\
\hline & Cholesterol crystals & Duewell et al. (42) \\
\hline & Silica & Hornung et al. (43), Kuroda et al. (44) and Cassel et al. (45) \\
\hline & Aluminum salts & Hornung et al. (43) and Kuroda et al. (44) \\
\hline & Amyloid-beta & Halle et al. (46) \\
\hline & Fatty acids & Wen et al. (47) \\
\hline & Mitochondrial DNA & Nakahira et al. (48) and Shimada et al. (49) \\
\hline & Aerolysin & Gurcel et al. (50) \\
\hline & Maitotoxin & Mariathasan et al. (51) \\
\hline & ATP & Mariathasan et al. (51) \\
\hline & Nigericin & Mariathasan et al. (51) \\
\hline & S. aureus & Craven et al. (52) \\
\hline & L. monocytogenes & Kim et al. (53) \\
\hline & P. gingivalis & Huang et al. (54) \\
\hline
\end{tabular}


Table 1 | Continued

\begin{tabular}{|c|c|c|}
\hline NLR protein & Activator & Reference \\
\hline & Chlamydia species & Abdul-Sater et al. (55) and He et al. (56) \\
\hline & Influenza A virus & Thomas et al. (57) and Allen et al. (58) \\
\hline & Aspergillus & Saïd-Sadier et al. (59) \\
\hline & Leishmania & Lima-Junior et al. (60) \\
\hline & ROS & Zhou et al. (61) \\
\hline \multirow[t]{5}{*}{ IPAF (NLRC4) } & Cytosolic flagellin & Franchi et al. (62) \\
\hline & L. pneumophila & Case et al. (63), Vinzing et al. (64) and Coers et al. (65) \\
\hline & S. typhimurium & Mariathasan et al. (66), Broz et al. (67) and Miao et al. (68) \\
\hline & S. flexneri & Suzuki et al. (69) \\
\hline & P. aeruginosa & Cohen and Prince (70), Sutterwala et al. (71) and Franchi et al. (72) \\
\hline \multirow[t]{2}{*}{ Naip5 } & Cytosolic flagellin (in cooperation with IPAF) & Zamboni et al. (73) \\
\hline & L. pneumophila & Lightfield et al. (74) and Zamboni et al. (73) \\
\hline
\end{tabular}

from the other NLRs (66). Another pathogen whose detection induces cell death through IPAF is L. pneumophila. However, in this case, another NLR protein, Naip5 (also known as Bircle), is required. Both Naip5 and IPAF have been reported to physically interact, but the role of Naip5 in caspase- 1 activation remains to be fully elucidated, as A/J mice (mice with a mutation that results in a non-functional Naip5) are able to secrete IL-1 $\beta$ following infection with S. typhimurium, P. aeruginosa, and L. monocytogenes (66, 71, 73) (Table 1).

Shigella flexneri also triggers IPAF-dependent activation of caspase- 1 and secretion of IL- $1 \beta$. These data are intriguing considering that $S$. flexneri is a non-flagellated bacterium, suggesting that other factors are able to activate IPAF (69). Indeed, more recent studies revealed that $P$. aeruginosa strains lacking flagellin are still able to induce secretion of IL-1 $\beta$ through NLRC4 (71) (Table 1).

Although the importance of IPAF in cytosolic flagella sensing is broadly recognized, it has been demonstrated that flagellindependent responses may occur in the absence of IPAF. Recently, a new pathway was reported in which macrophage stimulation with flagellin leads to cell death in a cathepsin B and D-dependent manner even in IPAF-deficient cells. It has yet to be determined whether a new flagellin sensor is involved in such events (82).

\section{NLRX1}

In contrast to the huge amount of data regarding other NLR proteins, little is known about the biological function of NLRX1. This protein is highly conserved among species and has sequence homology with Nod3. Unlike other NLRCs, NLRX1 has no CARD in its N-terminal portion but does have a putative mitochondrialtargeting sequence (83). Indeed, what we know about NLRX1 is derived from its mitochondrial localization, even though its precise localization inside this organelle is still a matter of debate. Studies from two independent groups report conflicting results; while Arnoult et al. claimed that NLRX1 is located in the mitochondrial matrix, Moore et al. proposed that the protein localizes to the outer mitochondrial membrane $(84,85)$. There are also discrepancies concerning the attributed function of NLRX1. Initial results from Tattoli et al. reported that NLRX1 amplifies NF- $\mathrm{B}$ and JNK through the production of ROS. Opposing results from Moore et al. suggest that NLRX1 functions as a brake on innate immune pathways by inhibiting mitochondrial antiviral signaling (MAVS)-dependent NF- $\mathrm{B}$ and IFN- $\beta$ production upon poly I:C stimulation in vitro (85, 86). Further studies are required to clarify of the function of NLRX1.

\section{NLRP4}

Very little is known about NLRP4, a 113-kDa protein also known as Nalp4 or PYPAF4. This protein is expressed in tissues as diverse as testis, oocytes, spleen, placenta, thymus, kidney, and lung. NLRP4 has been recently reported as a negative regulator of type I IFN signaling by targeting tank binding kinase-1 (TBK-1) for degradation as well as of TNF- $\alpha$ and IL- $1 \beta$ by inhibiting NF- $\kappa$ B activation by interacting with $\operatorname{IKK} \alpha(87,88)$.

\section{AUTOPHAGY}

The term autophagy (meaning "self-eating") was first introduced at the CIBA Foundation Symposium on Lysosomes in 1963 by cell biologist Christian de Duve, who also discovered lysosomes in 1955 (Nobel Prize in Physiology in 1974) and coined several other terms currently used today, such as "endocytosis" and "exocytosis." Autophagy was first characterized by the presence of single- or double-membrane vesicles harboring cytoplasmic content in different stages of degradation - the autophagosomes. At that time, de Duve and others considered autophagy to be a non-selective degradation pathway. However, under specific circumstances, autophagy is highly specific and plays essential roles in maintaining homeostasis. For a complete historical perspective on autophagy and its importance in different pathologies, please refer Ref. (89-91).

Autophagy is a highly conserved cellular homeostatic process in which long-lived proteins, damaged organelles, or parts of the cytosol are delivered to lysosomes for degradation and recycling of functional blocks for anabolic reactions, especially during nutrient shortages. Indeed, for years, autophagy was considered a mere response to nutritional stress given that initial observations demonstrated that glucagon or amino acid deprivation triggered the formation of autophagosomes while exogenous amino acids supplementation inhibited autophagy and protein breakdown (92). 


\section{THE MACHINERY OF AUTOPHAGOSOME BIOGENESIS}

So far, three types of autophagy have been described, chaperonemediated autophagy (CMA), microautophagy, and macroautophagy (hereafter, autophagy) (93). The hallmark of autophagy is the generation of autophagosomes. This process occurs in a stepwise manner controlled by over $30 \mathrm{Atg}$ genes that were initially identified in yeast species. Interestingly, most of these genes have mammalian orthologs or paralogs with high structural and functional similarities. Briefly, the process starts with the formation of a cup-shaped membrane or phagophore. Once formed, the membrane elongates and selectively and/or non-selectively enwraps the cargo (i.e., the cytosolic target), eventually sealing, completing the formation of the autophagosome. The outer membrane of the autophagosome the fuses with a lysosome membrane, forming the autolysosome, where all the degradation steps of the autophagic response take place (Figure 1). The source of the autophagosomal membrane is still a matter of debate. Various studies have proposed the plasma membrane, the endoplasmic reticulum or the outer mitochondrial membrane as the source (92).

\section{THE CORE AUTOPHAGY PATHWAY}

At the molecular level, the number of proteins implicated in the control of autophagy is still expanding and linking autophagy with several other pathways. Here, we focus on the core of the autophagic pathway and its links to NLR signaling. For autophagosomes formation, the following two ubiquitin-like (UBL) systems are required: (i) in the Atg12 conjugation system, $\operatorname{Atg} 5$ and $\operatorname{Atg} 12$ form complexes through the covalent binding of Atg12 to the C-terminal glycine of ATG5 in UBL reactions involving Atg7 and Atg10. Atg16L1, a scaffold protein, is then conjugated to the Atg5-Atg12 complex by binding to the N-terminus of Atg5. The Atg5-Atg12-Atg16L1 complex multimerizes, forming large $800 \mathrm{kDa}$ complexes that are found in the cytosol and in the forming membrane. It has been shown that the Atg16L1 complex acts as a E3-like enzyme, targeting microtubule-associated protein 1 light chain 3 (LC3) to its membrane site of lipid conjugation. (ii) The Atg8 conjugation system is crucial for inducing modifications in LC3. Under normal conditions, LC3 has a diffuse cytosolic distribution pattern. LC3 is cleaved at its C-terminus by Atg4, a cysteine protease, and undergoes UBL modifications by the E1-like enzyme, Atg7, and the E2-like enzyme, Atg3, to form LC3-I (94). During the induction of autophagy, the C-terminal carboxyl group of LC3-I is eventually conjugated with phosphatidylethanolamine to form LC3-II, which is found exclusively on the autophagosomal membrane. For this reason, LC3-II is widely used as an autophagy marker (95).

The Atg proteins, the autophagic machinery, seem to require other proteins to form autophagosomes. Similar to the Atg1-Atg13-Atg17 complex found in yeast, the Unc-51-like kinase (ULK1), focal adhesion kinase family integrating protein (FIP2000), and Atg13 proteins were described to colocalize at the nascent isolation membrane after induction of autophagy in mammalian cells $(96,97)$. Another protein that was shown to participate in autophagy is Atg9. Studies in mammals have demonstrated that Atg9 is essential for autophagosome formation as it associates with the trans-Golgi, endosomes, LC3, and Rab GTPases (Rab7 and Rab9) and redistributes following the induction of autophagy (92). In Figure 1, we summarize the main proteins and all the steps that are part of the formation of autophagosomes.

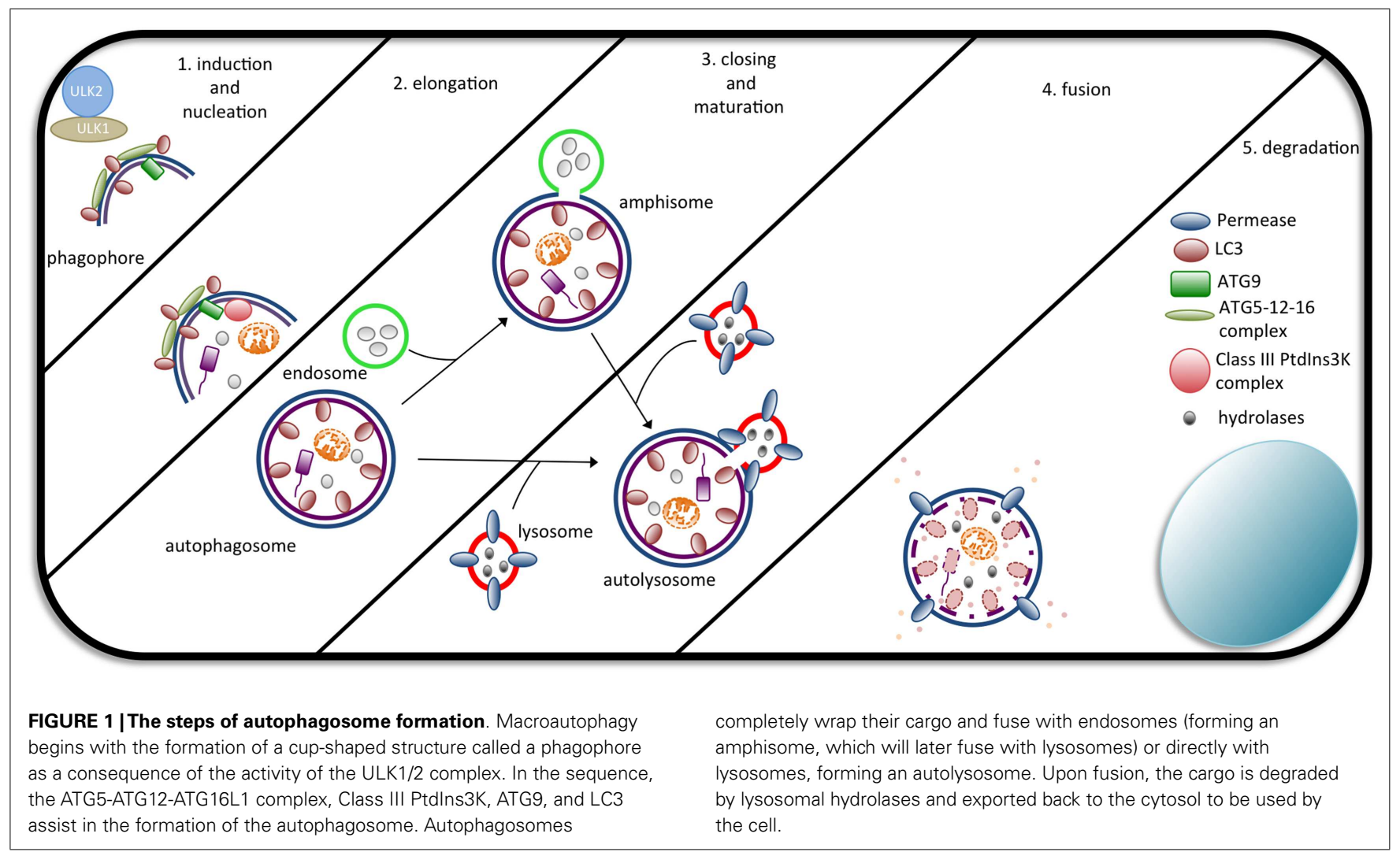


Interestingly, it has been proposed that autophagy may occur even in the absence of ATG proteins in both insects and mammals. However, the conditions that trigger ATG-independent autophagy and whether this type of autophagy is particular to some cell types remain to be determined $(98,99)$.

\section{CONTROL OF AUTOPHAGY}

The vast number of pathways that connect to autophagy gives rise to an intricate network that makes our understanding of autophagy regulation far from complete. A major breakthrough in understanding autophagy regulation was made when the target of rapamycin (TOR) in yeast and mammals was discovered, implicating the involvement of phosphatidylinositol kinase-related kinases in the process (100-102). Both pathways are linked by the key serine/threonine kinase Akt and are known to participate in several cellular responses such as proliferation and metabolic adaptation (92). Activators of phosphatidylinositol-3 kinase (PI3K) range from cytokines to TLR ligands. After receptor activation, phosphatidylinositol-4,5-biphosphate is phosphorylated by classI PI3K, activating Akt. mTOR complexes are effectors downstream of Akt and integrate a myriad of cellular signals, especially those related to protein synthesis and translation (103-106). Under optimal nutrient conditions, autophagy is negatively regulated by Akt and mTOR (107). This negative regulation of autophagy by mTOR has been recently shown to require inhibition of ULK kinasecomplex activity through its phosphorylation (108). At least in yeast, ULK1 seems to regulate autophagy not only by inhibiting mTOR but also by interacting with Atg8 (109). It remains to be tested whether these findings also apply in mammals. Another mechanism involved in the control of mTOR activation is the recruitment of TNF receptor-associated factor 6 (TRAF6) to the lysosome by $\mathrm{p} 62$, where it drives the polyubiquitination of mTOR during optimal nutrient conditions (110).

Upon the induction of autophagy, vacuolar protein sorting 34 (Vps34), a class III phosphatidylinositol-3-phosphate (PtdIns3P) kinase (PI3K) enzyme, specifically phosphorylates phosphatidylinositol and is implicated in trafficking, nutrient sensing, and autophagy $(111,112)$. In yeast, the role of PtdIns3P seems to go beyond autophagosomal membrane elongation. It has been proposed that the levels of PtdIns3P in the phagophore assembly site (PAS) regulate autophagosome turnover due to the accumulation of ATG proteins in the membrane (113). Other important players in autophagosome formation are Vps15, beclin-1, ultraviolet radiation resistance associated gene (UVRAG), and ambra1, which together form a multiprotein complex with Vps34 that is necessary for the initial steps in autophagosome formation. For a complete view of the autophagy pathway, see the review by Boya et al. (114).

\section{AUTOPHAGY AND IMMUNITY TO INFECTIONS}

The contamination of the cytosolic compartment with invasive pathogens is a major step in the activation of innate immune defenses. In this regard, autophagy has emerged in recent years as another component of the innate immune system's arsenal. Several microbial agents are recognized by the autophagic machinery, and their fates can vary from destruction to the creation of a replicative niche. It has been shown that the autophagic machinery can selectively segregate microbes in the cytosol. The mechanisms by which such specificity is achieved are not completely understood but seem to involve both microbial and host factors. Similar to MAMPs, which themselves were shown to induce autophagosome formation, toxins secreted by pathogens also induce autophagy (115). In a landmark paper, Nakagawa et al. demonstrated that group A Streptococcus (GAS) lacking streptolysin O (SLO) do not escape from phagocytic vacuoles, and thus, do not activate autophagic sequestration (116).

Gram-negative bacteria are recognized by the autophagic machinery as well. For example, S. flexneri uses a type 3 secretion system (T3SS) to deliver effector proteins directly into the host cell. Ogawa et al. showed that, in epithelial cells, the wild-type (WT) S. flexneri strain is capable of evading autophagic sequestration. This is dependent on the T3SS effector IcsB, as the mutant strain lacking IcsB is trapped by autophagy. The role of IcsB seems to be to camouflage the bacterial target molecule (VirG) from the autophagy machinery $(117,118)$. Interestingly, these observations seem to vary depending on cell type, given that in bone marrow-derived macrophages, no difference in bacteria sequestration was observed between the WT and IcsB mutant strains (69). The autophagic machinery apparently relies on redundant strategies to fight Shigella; different mechanisms have been described for the induction autophagy by this pathogen. In one mechanism, the phagocytic vacuolar membrane remnants, rather than bacterium itself, trigger autophagy in response to bacterial invasion (119).

Avoidance of autophagic destruction has also been reported for other bacteria. The Burkholderia pseudomallei T3SS effector, BopA, which shares some homology with IcsB, contributes to bacterial evasion from autophagosome targeting (120). The Gram-positive bacterium L. monocytogenes is able to invade host cells, where it finds a replicative niche within the cytosol following autophagosome escape. These events are dependent on the expression of listeriolysin O (LLO), ActA, and phospholipase C (121).

However, autophagy can serve as a back-up control mechanism for bacteria that are able to escape from other defense mechanisms. For example, after invading the host cell, S. typhimurium resides within vacuoles called Salmonella-containing vacuoles (SCV). Following SCV damage mediated by its T3SS, S. typhimurium gains access to the cytosol where autophagy is immediately activated to confine the bacteria and restrict the infection (122). In the case of M. tuberculosis, which is known to subvert host cell phagosomal maturation and survive within macrophages, autophagy induction via rapamycin or IFN- $\gamma$ circumvents the phagosomal maturation blockade, leading to M. tuberculosis elimination (123).

Viral pathogens interact with the autophagic pathway as well. Herpes simplex virus (HSV) ICP34.5 interacts with beclin-1 and blocks autophagosome formation (124). In vesicular stomatitis virus (VSV)-infected DCs, autophagy is essential for the delivery of viral ligands to endosomes to induce type I IFN production (125).

\section{NLR-MEDIATED AUTOPHAGY AND INFECTION}

As mentioned before, the first line of host defense against infection relies on various families of PRMs. As it became evident that autophagy is also an innate immune effector mechanism, considerable efforts were made to understand the role of PMRs in the autophagic response to pathogens.

The first study linking MAMP sensing and autophagy induction was the work by $\mathrm{Xu}$ et al. who showed a role for TLRs in 
autophagy. TLRs are transmembrane proteins that recruit myeloid differentiation primary response protein 88 (MyD88) and Toll-IL1 receptor (TIR) domain-containing adapter-inducing IFN (Trif) adapter proteins through their TIR domain to initiate downstream signaling. It was demonstrated that LPS induces autophagy in a TLR4-p38-RIP1-Trif-dependent manner (126). Later, a report from Delgado et al. showed that TLR7 could elicit similar responses upon stimulation of macrophages with ssRNA, and this was also dependent on the recruitment of MyD88 (127). The balance between Beclin-1 and Bcl-2 is a major checkpoint in the pathway for autophagy induction. Shi et al. (128) proposed that MyD88 and Trif both target Beclin-1, resulting in decreased binding to Bcl-2 and subsequent autophagy activation upon TLR stimulation. MyD88 and interferon-regulatory factors (IRFs) 5 and 7 are also recruited by mTOR to control cytokine production $(128,129)$.

Despite increasing evidence showing a role for TLRs in the induction of autophagy, it remains unclear how the autophagic machinery is directed to trap an entire microorganism during infection, especially considering that they are transmembrane proteins. Several bacteria, such as Salmonella, Mycobacterium, and Listeria, grow within host cells and by doing so can avoid antibody and cellular dependent defenses. Intracellular PRMs, such as the NLR family, are known for their essential role as cytosolic sentinels that can trigger robust cytokine production and inflammation. However, little was known regarding how these sensors contribute to the elimination of intracellular invaders. The first evidence implicating NLRs in autophagy-dependent control of an intracellular infection came from studies using Drosophila as a model. Yano et al. (130) reported that, upon infection of hemocytes with L. monocytogenes, Drosophila PGRP-LE detects diaminopimelic (DAP)-containing PG to trigger autophagy directed against the bacterium. Consistent with these observations, PGRP-LE null mutants were more susceptible to infection (130). The recognition of intracellular PG and subsequent induction of autophagy seem to be conserved features of the innate immune system. In 2010, two independent studies reported Nod1- and Nod2dependent autophagy upon PG detection. We showed that Nod1 and Nod2 direct autophagy by recruiting ATG16L1 to the plasma membrane during bacterial entry into the host cell (Figure 1). Interestingly, the most common mutation in Nod2 associated with CD, Nod21007fs, results in a protein that fails to recruit ATG16L1 to initiate the formation of autophagosomes, although they still interact in the cytosol. In another study, Cooney et al. (131) found that Nod2 induces autophagy in human DCs, increasing bacterial killing, and antigen presentation. DCs expressing CD-associated variants displayed lower autophagy and antigen presentation levels upon MDP stimulation. Interestingly, while we demonstrated that the adaptor protein Rip 2 and NF- $\kappa \mathrm{B}$ activation is dispensable for autophagy induction because Rip2-deficient fibroblasts displayed similar numbers of $S$. flexneri targeted to autophagosomes, Cooney et al. found that Rip2-deficient DCs had reduced levels of autophagy. The difference in the cell types used could account for such differences $(131,132)$.

These studies gained additional relevance as a recent link between polymorphisms in ATG16L1 and CD was uncovered. $\mathrm{CD}$ and ulcerative colitis (UC) are common presentations of idiopathic IBD. It is estimated that their prevalence in Caucasian individuals reaches $100-150$ per 100,000 (133). IBD is the outcome of combined genetic and non-genetic risk factors, and recently genome wide association studies (GWAS) have identified a non-synonymous single nucleotide polymorphism in ATG16L1 (T300A) as one of the most important genetic risk factors for CD. Studies in which the implications of this polymorphism were analyzed show that MDP-induced but not canonical autophagy is impaired in cells of individuals carrying the T300A variant (131, 132). The effect of this polymorphism on the restriction of bacterial growth varies depending on the cellular and bacterial models used. Epithelial cells expressing the T300A variant show decreased bacteria-targeted autophagy during infection with S. typhimurium (134). Monocytes from patients with CD and carrying the T300A allele infected with $M$. avium paratuberculosis display no difference in bacterial growth in comparison to patients with the normal allele (135). The impact of this variant on cytokine release has also been evaluated, and again, contradictory findings were observed. Plantinga et al. (136) reported that upon Nod2 stimulation with MDP (but not with TLR ligands), PBMCs from healthy volunteers carrying the T300A variant secreted increased amounts of IL-1 $\beta$ (136). In contrast, in another study, the same group demonstrated that PBMCs with the variant allele do not produce more IL-1 $\beta$ in comparison to the normal allele upon infection with $M$. tuberculosis (137).

Legionella pneumophila, a Gram-negative pathogen of amebae, is also able to replicate within alveolar macrophages and cause the pneumonia known as Legionnaire's disease. Mouse macrophages, in contrast to human cells, restrict L. pneumophila replication through the activation of Naip 5 and NLRC4 by cytosolic flagellin and activation of caspase- 1 resulting in pyroptosis. In a recent study, Byrne et al. demonstrated that flagellin recognition by Naip 5 and NLRC4 increases autophagosome turnover (138).

NLRX1 has been shown to enhance autophagy. A recent study demonstrated that NLRX1 enhances autophagy through interaction with the Tu translation elongation factor (TUFM) which, in turn, interacts with the Atg5-Atg12 complex. It is not clear, however, how this NLRX1-TUFM-Atg5-Atg12 interaction leads to increased autophagy. Still, NLRX1 plays an important role as a pro-autophagic factor during vesicular stomatitis (VSV) infection. Lei et al. (139) showed decreased viral replication in NLRX1deficient fibroblasts, suggesting that autophagy is important for VSV replication, although a previous work demonstrated that VSV succumbs to autophagy in a Drosophila model $(139,140)$. Of note is the fact that the role of NLRX1 in autophagy varies among studies using the different NLRX1 knockout mice available. While Soares et al. and Rebsamen et al. found that the MAVS pathway is fully functional in their NLRX1-deficient mice, Allen et al. reported an enhancement in this signaling pathway using a different NLRX1 knockout mice [the same used by Lei et al. $(139,141-143)]$. It remains to be determined whether the role of NLRX1 in autophagy is specific to the knockout animals used by Lei et al. or if it is a general feature of all NLRX1-deficient mice (Figure 2B).

Finally, in contrast to what was described above, NLRs can also act as negative regulators of autophagy through mechanisms that are not yet completely elucidated. Suzuki et al. reported that NLRC4- and caspase-1-deficient macrophages display increased targeting of S. flexneri to autophagosomes (69). Similar results were found in a study analyzing the impact of NLRC4 and NLRP4 


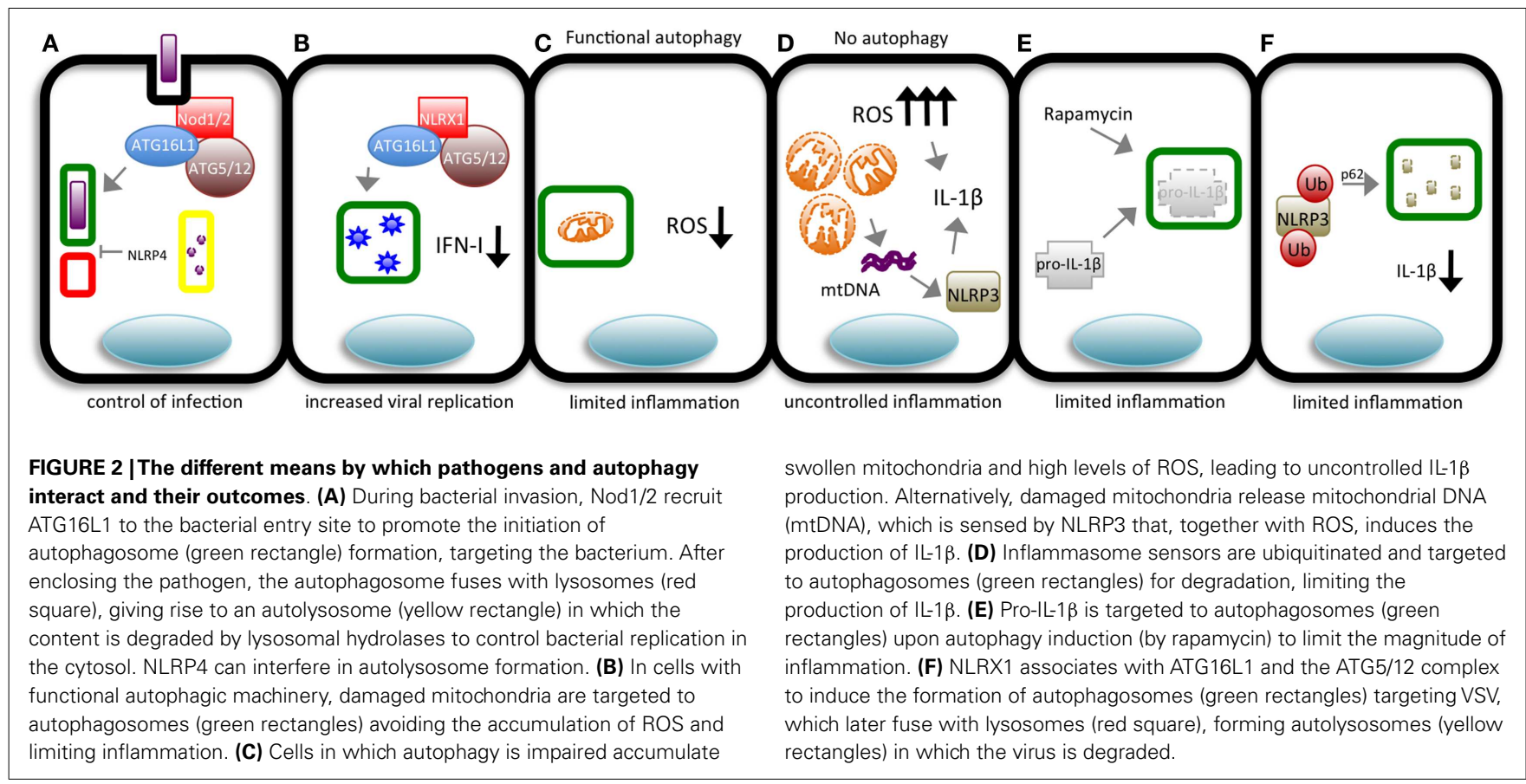

on autophagy, where it was demonstrated that epithelial cells with both proteins silenced displayed enhanced autophagy. A partial explanation for these observations is that NLRP4 is part of the Beclin-1 and C-VPS (a complex consisting of VPS11, VPS16, VPS18, and Rab7 that controls membrane tethering and fusion of vacuolar membranes) complexes, which are essential for the biogenesis and maturation of autophagosomes, respectively (144). The elucidation of the precise mechanisms by which NLRP4 exerts its negative effects on autophagy requires further studies (Figure 2A).

\section{AUTOPHAGY-DEPENDENT CONTROL OF NLR-DEPENDENT INFLAMMATION}

Another function of autophagy seems to be the control of the magnitude of inflammatory responses (145). In the last few years, several groups have reported that autophagy blockade by pharmacological or genetic means leads to increased production of cytokines by different mechanisms. Two independent studies have shown that ATG5-deficient fibroblasts produce significantly more IFN-I and IL-6 then WT cells during viral infection. The mechanisms likely involve the interaction between ATG12-ATG5 complexes with IPS-1, RIG-I, and MDA-5 and accumulation of damaged mitochondria in the autophagy-deficient cells, as discussed below $(146,147)$.

\section{AUTOPHAGY AND INFLAMMASOMES A ROLE FOR ROS}

As discussed above, the cells deficient in ATG genes produce increased levels of pro-inflammatory cytokines $(146,147)$. Tal et al. (147) demonstrated a vital role of autophagy in the removal of damaged mitochondria (mitophagy), and thus, in cell homeostasis. Cells with defects in autophagy, such as Atg5-deficient cells, accumulate damaged mitochondria, and consequently present increased levels of ROS. This in turn results in the enhancement of the levels of IFN $\alpha$ and IL-6 production upon infection with VSV. In addition, the authors show that by using the antioxidants $N$-acetyl- $L$-cysteine (NAC) and propyl-gallate (PG) during VSV infection, they were able to revert the increase in cytokine production. The removal of damaged mitochondria can be regulated by adapter proteins that participate in NLR-activating pathways. For example, besides its well-known and crucial role linking Nod1 and Nod2 sensing to NF-kB activation, Rip2 has also been implicated in mitophagy. In a recent study, Lupfer et al. showed that Rip2 regulates mitophagy through ULK1 to keep ROS at basal levels. Genetic deletion of Rip2 leads to the accumulation of ROS and significantly higher levels of IL-18 and IFN- $\gamma$ upon influenza infection (148) (Figure 2C).

Among all the cytokines that have been studied, IL- $1 \beta$ seems to be the cytokine whose production is most dramatically affected by autophagy. Processing and activation of pro-IL- $1 \beta$ into its active form depends on the assembly of inflammasomes. Increased ROS levels seem to be a prerequisite for inflammasome activation. The manipulation of autophagy by pharmacological or genetic means has a profound impact on IL- $1 \beta$ production and secretion during infection or LPS treatment. Indeed, the use of the autophagy inhibitor 3-methyladenine (3-MA), deletion of LC3B or ATG16L1, silencing of Beclin-1 or dominant negative forms of the cysteine protease ATG4B all lead to remarkably higher amounts of IL- $1 \beta$ $(48,149-151)$. The first evidence to show that autophagy can modulate IL- $1 \beta$ production surfaced in 2008 with the work of Saitoh et al. These authors reported that macrophages from ATG16L1deficient mice produced much higher levels of IL-1 $\beta$ after LPS exposure and that this was not due to defects in the generation of pro-IL-1 $\beta$ and pro-caspase-1. These authors proposed a model in which TRIF and loss of $\mathrm{K}^{+}$and ROS are required for the activation of inflammasomes, and subsequently, IL-1 $\beta$ processing (150). However, it remains to be shown that these observations were not due to defective mitophagy. Further studies not only 
confirmed but expanded the evidence for the requirement of functional autophagy for the maintenance of basal levels of ROS, and subsequently, for the control of inflammasome activation. In an elegant study, Nakahira et al. dissected the role of autophagy in the activation of the NLRP3 inflammasome. In a series of experiments in which autophagy was inhibited either by deletion of LC3B or by heterozygous deletion of Beclin-1, a robust increase in IL-1 $\beta$ processing and release was observed following stimulation with LPS plus ATP. According to the authors, these stimuli led to swollen mitochondria and the release of its DNA (mtDNA). In $\rho^{0}$ J774A.1 macrophages, the release of mtDNA into the cytosol is blocked, and IL-1 $\beta$ secretion is impaired. Similar results were obtained when cells were treated with DNAse I. Interestingly, the production of ROS and consequent activation of the inflammasome were dependent on the presence of cytosolic mtDNA. Altogether, the results from this study delineate a model in which LPS plus ATP induce mitochondrial damage, ROS production, and NLRP3-dependent release of mtDNA into the cytosol, resulting in the activation of caspase- 1 and release of IL-1 $\beta$ (48). The findings reported by Nakahira et al. were partially contradicted by a more recent study that suggests that ATP actually induces the release of oxidized mtDNA, which in turn binds to NLRP3 to induce IL$1 \beta$ production. Oxidized mtDNA was not detected in the cytosol of NLPR3-deficient macrophages. According to the authors, this could be explained by the fact that unbound oxidized mtDNA is rapidly degraded, but this later observation still lacks experimental confirmation (49) (Figure 2D). It is important to note that the idea of ROS as an activator of NLPR3 inflammasomes was challenged by a study demonstrating that ROS is key for priming of NLRP3 but not for its activation. One way or another, it is clear that ROS is necessary for IL- $1 \beta$ production (152).

The source of ROS required for inflammasome activation is also a matter of debate. Initial reports suggested that nicotinamide dinucleotide phosphate (NADPH) oxidases were the main source for inflammasome activation (153). The NADPH complex comprises the membrane-bound gp $91^{\text {phox }}$ and $\mathrm{p} 22^{\text {phox }}$ glycoproteins and the cytosolic components $\mathrm{p} 47^{\text {phox }}$ and $\mathrm{p} 67^{\text {phox }}$. Patients with chronic granulomatous disease (CGD) can have mutations in any of the $\mathrm{NADPH}$ oxidases and as a result present defective phagocytes because their cells have impaired capacity to generate superoxide anion and its metabolites, hydrogen peroxide, the hydroxyl anion, and hypohalous acid (154). Meissner et al. reported that in monocytes from CGD patients with mutations in gp91 ${ }^{\text {phox }}, \mathrm{p} 22^{\text {phox }}$, and $\mathrm{p} 47^{\text {phox }}$, stimulation with LPS plus ATP led to the activation of caspase- 1 and secretion of mature IL-1 $\beta$ (155). Furthermore, monocytes from CGD patients presented elevated IL- $1 \beta$ levels in comparison to monocytes from healthy controls (154). These findings challenged the notion that NADPH oxidases are the source of ROS necessary to induce inflammasome activation. This question was apparently clarified by the work of Zhou et al. which demonstrated that ROS generated by dysfunctional mitochondria [mtROS, achieved by either by treating cells with the complex I inhibitor, rotenone, or silencing of the voltage-dependent anion channel (VDAC) ] activates the Nlrp3 inflammasome. The requirement of mtROS for activation of the inflammasome seems to be specific for Nlrp3 because VDAC1 silencing did not influence activation of NLRC4 of AIM2 inflammasomes. Once again, the crucial role of autophagy in clearing damaged mitochondria was demonstrated in the work of Zhou et al. in which 3-MA treatment or beclin-1 or Atg5 silencing resulted in ROS accumulation and inflammasome activation (61).

As already mentioned, mutations in NLR genes are associated with increased risk for inflammatory diseases. Auto-activation of the NLRP3 inflammasome has been linked to several autosomal dominant cryopyrinopathies or cryopyrin-associated periodic fever syndromes (CAPS), such as familial cold-induced autoinflammatory syndrome (FCAS), Muckle-Wells syndrome (MWS), and neonatal onset multisystem inflammatory disorder or chronic infantile neurologic cutaneous and articular syndrome (NOMID/CINCA) (156). These syndromes, despite their different names, represent a continuum of disease severity where FCAS is the mildest and NOMID/CINCA the most severe. These cryopyrinopathies are associated with periodic fever, rashes, arthralgia, and conjunctivitis, and the aberrant production of IL- $1 \beta$ is the most prominent feature related to all these manifestations (6).

The increasing incidence of T2D has become a global health burden. TD2 has been associated with low-grade inflammation that leads to insulin resistance. In this context, IL- $1 \beta$ is one of the main cytokines implicated in T2D, mediating the destruction of beta cells and resulting in insulin resistance in cells that were initially sensitive to the hormone. A high-fat diet (HFD) is one of the factors associated with T2D. Indeed, T2D patients display augmented levels of free fatty acids in the serum. In a recent study, Wen et al. demonstrated in a bone marrow-derived model that palmitate, an abundant saturated fatty acid in the plasma, inhibits AMP-activated protein kinase (AMPK), leading to defective autophagy, and thus, ROS accumulation. These events contribute to the elevation of IL- $1 \beta$ production and impairment of insulin signaling in vitro (47).

A recent report showed that autophagy is involved not only in IL- $1 \beta$ production but also in its secretion. Macrophages from Atg 5 conditional knockout mice secreted significantly more IL- $1 \beta$ during the induction of autophagy triggered by starvation. These observations need further confirmation (157).

\section{A ROLE FOR UBIOUITIN}

As in many aspects of its biology, autophagy has ambiguous roles in regulating inflammasome activation and acts both as a positive and negative regulator depending on the experimental model.

In a recent study, Harris et al. provided experimental evidence that autophagy controls inflammasomes by targeting its components to autophagosomes. These authors showed that proIL- $1 \beta$ is delivered to autophagosomes after TLR stimulation. Upon autophagy induction by rapamycin treatment, pro-IL- $1 \beta$ is degraded, limiting the amount available for the processing and secretion of IL-1 $\beta$ (149) (Figure 2E).

One mechanism underlying the targeting of inflammasome proteins to autophagosomes seems to be ubiquitination. In a recent study by Shi et al. it was demonstrated that inflammasomes containing ASC are directed to autophagosomes during NLRP3 or AIM2 activation in primary macrophages. They also provided evidence that beclin-1 and p62 are involved in targeting ASC to autophagosomes after it is K63 ubiquitination. The results presented suggest that by using its separate UBA 
and LIR domains, p62/SQTM1 bridges ASC K623 ubiquitination, and autophagy-dependent degradation (151). In addition to ASC, NLRP3 is also ubiquitinated in a mtDNA-, ROS-, and ATP-dependent manner, but its delivery into autophagosomes has not yet been demonstrated (158) (Figure 2F).

\section{CONCLUDING REMARKS}

The NLR and autophagy fields are two exciting research areas in biology with many unanswered questions related to the precise mechanisms that coordinate the "talk" between NLR proteins and autophagy. It will be interesting to discover in more detail whether autophagy modulation can be used to control NLR-dependent immune pathways to improve therapeutic strategies for inflammatory and infectious diseases. In light of the recent findings that connect autophagy and inflammasome regulation, it remains to be determined whether alterations in autophagy could explain, at least in part, the dysregulated production of IL-1 $\beta$ in NLRP3associated cryopyrinopathies. We believe that in the near future, some of the findings discussed in the present review have the potential to be translated into new therapeutic strategies that can be applied in daily medical practice.

\section{REFERENCES}

1. Philpott DJ, Yamaoka S, Israel A, Sansonetti PJ. Invasive Shigella flexneri activates NF-kappa B through a lipopolysaccharide-dependent innate intracellular response and leads to IL-8 expression in epithelial cells. J Immunol (2000) 165:903-14.

2. Fritz JH, Ferrero RL, Philpott DJ, Girardin SE. Nod-like proteins in immunity, inflammation and disease. Nat Immunol (2006) 7:1250-7. doi:10.1038/ni1412

3. Bonardi V, Cherkis K, Nishimura MT, Dangl JL. A new eye on NLR proteins: focused on clarity or diffused by complexity? Curr Opin Immunol (2012) 24:41-50. doi:10.1016/j.coi.2011.12.006

4. Girardin SE, Boneca IG, Viala J, Chamaillard M, Labigne A, Thomas G, et al. Nod2 is a general sensor of peptidoglycan through muramyl dipeptide (MDP) detection. J Biol Chem (2003) 278:8869-72. doi:10.1074/jbc.C200651200

5. Inohara N, Ogura Y, Fontalba A, Gutierrez O, Pons F, Crespo J, et al. Host recognition of bacterial muramyl dipeptide mediated through NOD2. Implications for Crohn's disease. J Biol Chem (2003) 278:5509-12. doi:10.1074/jbc. C200673200

6. Carneiro L, Magalhaes JG, Tattoli I, Philpott DJ, Travassos LH. Nod-like proteins in inflammation and disease. J Pathol (2008) 214:136-48. doi:10.1002/ path. 2271

7. Travassos LH, Carneiro LAM, Girardin SE, Boneca IG, Lemos R, Bozza MT, et al. Nodl participates in the innate immune response to Pseudomonas aeruginosa. J Biol Chem (2005) 280:36714-8. doi:10.1074/jbc.M501649200

8. Girardin SE, Boneca IG, Carneiro LAM, Antignac A, Jéhanno M, Viala J, et al. Nod1 detects a unique muropeptide from gram-negative bacterial peptidoglycan. Science (2003) 300:1584-7. doi:10.1126/science.1084677

9. Chamaillard M, Hashimoto M, Horie Y, Masumoto J, Qiu S, Saab L, et al. An essential role for NOD1 in host recognition of bacterial peptidoglycan containing diaminopimelic acid. Nat Immunol (2003) 4:702-7. doi:10.1038/ni945

10. Uehara A, Yang S, Fujimoto Y, Fukase K, Kusumoto S, Shibata K, et al. Muramyldipeptide and diaminopimelic acid-containing desmuramylpeptides in combination with chemically synthesized toll-like receptor agonists synergistically induced production of interleukin-8 in a NOD2- and NOD1dependent manner, respectively, in human monocytic cells in culture. Cell Microbiol (2005) 7:53-61. doi:10.1111/j.1462-5822.2004.00433.x

11. Magalhaes JG, Philpott DJ, Nahori M-A, Jéhanno M, Fritz J, Bourhis LL, et al. Murine Nodl but not its human orthologue mediates innate immune detection of tracheal cytotoxin. EMBO Rep (2005) 6:1201-7. doi:10.1038/sj.embor. 7400552

12. Uehara A, Fujimoto Y, Kawasaki A, Kusumoto S, Fukase K, Takada H. Mesodiaminopimelic acid and meso-lanthionine, amino acids specific to bacterial peptidoglycans, activate human epithelial cells through NOD1. J Immunol (2006) 177:1796-804.
13. Hasegawa M, Yang K, Hashimoto M, Park J-H, Kim Y-G, Fujimoto Y, et al. Differential release and distribution of Nod1 and Nod2 immunostimulatory molecules among bacterial species and environments. J Biol Chem (2006) 281:29054-63. doi:10.1074/jbc.M602638200

14. Le Bourhis L, Magalhaes JG, Selvanantham T, Travassos LH, Geddes K, Fritz JH, et al. Role of Nod1 in mucosal dendritic cells during Salmonella pathogenicity island 1-independent Salmonella enterica serovar typhimurium infection. Infect Immun (2009) 77:4480-6. doi:10.1128/IAI.00519-09

15. Viala J, Chaput C, Boneca IG, Cardona A, Girardin SE, Moran AP, et al. Nod1 responds to peptidoglycan delivered by the Helicobacter pylori cag pathogenicity island. Nat Immunol (2004) 5:1166-74. doi:10.1038/ni1131

16. Kavathas PB, Boeras CM, Mulla MJ, Abrahams VM. Nod1, but not the ASC inflammasome, contributes to induction of IL- $1 \beta$ secretion in human trophoblasts after sensing of Chlamydia trachomatis. Mucosal Immunol (2013) 6:235-43. doi:10.1038/mi.2012.63

17. Buchholz KR, Stephens RS. The cytosolic pattern recognition receptor NOD1 induces inflammatory interleukin-8 during Chlamydia trachomatis infection. Infect Immun (2008) 76:3150-5. doi:10.1128/IAI.00104-08

18. Welter-Stahl L, Ojcius DM, Viala J, Girardin S, Liu W, Delarbre C, et al. Stimulation of the cytosolic receptor for peptidoglycan, Nod1, by infection with Chlamydia trachomatis or Chlamydia muridarum. Cell Microbiol (2006) 8:1047-57. doi:10.1111/j.1462-5822.2006.00686.x

19. Opitz B. Nod1-mediated endothelial cell activation by Chlamydophila pneumoniae. Circ Res (2005) 96:319-26. doi:10.1161/01.RES.0000155721.83594.2c

20. Park J-H, Kim Y-G, Shaw M, Kanneganti T-D, Fujimoto Y, Fukase K, et al. Nod1/RICK and TLR signaling regulate chemokine and antimicrobial innate immune responses in mesothelial cells. J Immunol (2007) 179:514-21.

21. Kim Y-G, Park J-H, Daignault S, Fukase K, Nuñez G. Cross-tolerization between Nod 1 and Nod 2 signaling results in reduced refractoriness to bacterial infection in Nod2-deficient macrophages. J Immunol (2008) 181:4340-6.

22. Opitz B, Püschel A, Beermann W, Hocke AC, Förster S, Schmeck B, et al. Listeria monocytogenes activated p38 MAPK and induced IL- 8 secretion in a nucleotide-binding oligomerization domain 1-dependent manner in endothelial cells. J Immunol (2006) 176:484-90.

23. Kim JG, Lee SJ, Kagnoff MF. Nod1 is an essential signal transducer in intestinal epithelial cells infected with bacteria that avoid recognition by toll-like receptors. Infect Immun (2004) 72:1487-95. doi:10.1128/IAI.72.3.1487-1495. 2004

24. Girardin SE, Tournebize R, Mavris M, Page AL, Li X. CARD4/Nod1 mediates NF- $\kappa$ B and JNK activation by invasive Shigella flexneri. EMBO Rep (2001) 2(8):736-42. doi:10.1093/embo-reports/kve155

25. Carneiro LAM, Travassos LH, Soares F, Tattoli I, Magalhaes JG, Bozza MT, et al. Shigella induces mitochondrial dysfunction and cell death in nonmyleoid cells. Cell Host Microbe (2009) 5:123-36. doi:10.1016/j.chom.2008.12.011

26. Al-Sayeqh AF, Loughlin MF, Dillon E, Mellits KH, Connerton IF. Campylobacter jejuni activates NF-kappaB independently of TLR2, TLR4, Nod1 and Nod2 receptors. Microb Pathog (2010) 49:294-304. doi:10.1016/j.micpath.2010.06. 011

27. Zilbauer M, Dorrell N, Elmi A, Lindley KJ, Schüller S, Jones HE, et al. A major role for intestinal epithelial nucleotide oligomerization domain 1 (NOD1) in eliciting host bactericidal immune responses to Campylobacter jejuni. Cell Microbiol (2007) 9:2404-16. doi:10.1111/j.1462-5822.2007.01008.x

28. Silva GK, Gutierrez FRS, Guedes PMM, Horta CV, Cunha LD, Mineo TWP, et al. Cutting edge: nucleotide-binding oligomerization domain 1-dependent responses account for murine resistance against Trypanosoma cruzi infection. J Immunol (2010) 184:1148-52. doi:10.4049/jimmunol.0902254

29. Sabbah A, Chang TH, Harnack R, Frohlich V, Tominaga K, Dube PH, et al. Activation of innate immune antiviral responses by Nod2. Nat Immunol (2009) 10:1073-80. doi:10.1038/ni.1782

30. Juárez E, Carranza C, Hernández-Sánchez F, León-Contreras JC, HernándezPando R, Escobedo D, et al. NOD2 enhances the innate response of alveolar macrophages to Mycobacterium tuberculosis in humans. Eur J Immunol (2012) 42:880-9. doi:10.1002/eji.201142105

31. Ferwerda G, Girardin SE, Kullberg B-J, Le Bourhis L, de Jong DJ, Langenberg DML, et al. NOD2 and toll-like receptors are nonredundant recognition systems of Mycobacterium tuberculosis. PLoS Pathog (2005) 1:e34. doi:10.1371/journal.ppat.0010034

32. Divangahi M, Mostowy S, Coulombe F, Kozak R, Guillot L, Veyrier F, et al. NOD2-deficient mice have impaired resistance to Mycobacterium tuberculosis 
infection through defective innate and adaptive immunity. J Immunol (2008) 181:7157-65.

33. Travassos LH, Girardin SE, Philpott DJ, Blanot D, Nahori M-A, Werts C, et al. Toll-like receptor 2-dependent bacterial sensing does not occur via peptidoglycan recognition. EMBO Rep (2004) 5:1000-6. doi:10.1038/sj.embor. 7400248

34. Liu X, Chauhan VS, Young AB, Marriott I. NOD2 mediates inflammatory responses of primary murine glia to Streptococcus pneumoniae. Glia (2010) 58:839-47. doi:10.1002/glia.20968

35. Kufer TA, Kremmer E, Banks DJ, Philpott DJ. Role for erbin in bacterial activation of Nod2. Infect Immun (2006) 74:3115-24. doi:10.1128/IAI.00035-06

36. Keestra AM, Winter MG, Klein-Douwel D, Xavier MN, Winter SE, Kim A, et al. A Salmonella virulence factor activates the NOD1/NOD2 signaling pathway. MBio (2011) 2(6):e00266-11. doi:10.1128/mBio.00266-11

37. Hisamatsu T, Suzuki M, Reinecker H-C, Nadeau WJ, McCormick BA, Podolsky DK. CARD15/NOD2 functions as an antibacterial factor in human intestinal epithelial cells. Gastroenterology (2003) 124:993-1000. doi:10.1053/gast.2003. 50153

38. Kobayashi M, Wilson AC, Chao MV, Mohr I. Control of viral latency in neurons by axonal mTOR signaling and the 4E-BP translation repressor. Genes Dev (2012) 26:1527-32. doi:10.1101/gad.190157.112

39. Martinon F, Agostini L, Meylan E, Tschopp J. Identification of bacterial muramyl dipeptide as activator of the NALP3/cryopyrin inflammasome. Curr Biol (2004) 14(21):1929-34. doi:10.1016/j.cub.2004.10.027

40. Kanneganti TD, Ozoren N, Body-Malapel M, Amer A. Bacterial RNA and small antiviral compounds activate caspase-1 through cryopyrin/Nalp3. Nature (2006) 440(7081):233-6. doi:10.1038/nature04517

41. Martinon F, Pétrilli V, Mayor A, Tardivel A, Tschopp J. Gout-associated uric acid crystals activate the NALP3 inflammasome. Nat Cell Biol (2006) 440:237-41. doi:10.1038/nature 04516

42. Duewell P, Kono H, Rayner KJ, Sirois CM, Vladimer G, Bauernfeind FG, et al. NLRP3 inflammasomes are required for atherogenesis and activated by cholesterol crystals. Nature (2010) 464:1357-61. doi:10.1038/nature08938

43. Hornung V, Bauernfeind F, Halle A, Samstad EO, Kono H, Rock KL, et al. Silica crystals and aluminum salts activate the NALP3 inflammasome through phagosomal destabilization. Nat Immunol (2008) 9:847-56. doi:10.1038/ni.1631

44. Kuroda E, Ishii KJ, Uematsu S, Ohata K, Coban C, Akira S, et al. Silica crystals and aluminum salts regulate the production of prostaglandin in macrophages via NALP3 inflammasome-independent mechanisms. Immunity (2011) 34:514-26. doi:10.1016/j.immuni.2011.03.019

45. Cassel SL, Eisenbarth SC, Iyer SS, Sadler JJ, Colegio OR, Tephly LA, et al. The Nalp3 inflammasome is essential for the development of silicosis. Proc Natl Acad Sci U S A (2008) 105:9035-40. doi:10.1073/pnas.0803933105

46. Halle A, Hornung V, Petzold GC, Stewart CR, Monks BG, Reinheckel T, et al. The NALP3 inflammasome is involved in the innate immune response to amyloid-beta. Nat Immunol (2008) 9:857-65. doi:10.1038/ni.1636

47. Wen H, Gris D, Lei Y, Jha S, Zhang L, Huang MT-H, et al. Fatty acid-induced NLRP3-ASC inflammasome activation interferes with insulin signaling. Nat Immunol (2011) 12:408-15. doi:10.1038/ni.2022

48. Nakahira K, Haspel JA, Rathinam VAK, Lee S-J, Dolinay T, Lam HC, et al. Autophagy proteins regulate innate immune responses by inhibiting the release of mitochondrial DNA mediated by the NALP3 inflammasome. Nat Immunol (2011) 12:222-30. doi:10.1038/ni.1980

49. Shimada K, Crother TR, Karlin J, Dagvadorj J, Chiba N, Chen S, et al. Oxidized mitochondrial DNA activates the NLRP3 inflammasome during apoptosis. Immunity (2012) 36:401-14. doi:10.1016/j.immuni.2012.01.009

50. Gurcel L, Abrami L, Girardin S, Tschopp J, van der Goot FG. Caspase-1 activation of lipid metabolic pathways in response to bacterial pore-forming toxins promotes cell survival. Cell (2006) 126:1135-45. doi:10.1016/j.cell.2006.07.033

51. Mariathasan S, Weiss DS, Newton K, McBride J, O’Rourke K, Roose-Girma M, et al. Cryopyrin activates the inflammasome in response to toxins and ATP. Nature (2006) 440:228-32. doi:10.1038/nature04515

52. Craven RR, Gao X, Allen IC, Gris D, Wardenburg JB. Staphylococcus aureus $\alpha$-hemolysin activates the NLRP3-inflammasome in human and mouse monocytic cells. PLoS One (2009) 4(10):e7446. doi:10.1371/journal.pone. 0007446

53. Kim S, Bauernfeind F, Ablasser A. Listeria monocytogenes is sensed by the NLRP3 and AIM2 inflammasome. Eur J Immunol (2010) 40:1545-51. doi:10.1002/eji. 201040425
54. Huang MT-H, Taxman DJ, Holley-Guthrie EA, Moore CB, Willingham SB, Madden V, et al. Critical role of apoptotic speck protein containing a caspase recruitment domain (ASC) and NLRP3 in causing necrosis and ASC speck formation induced by Porphyromonas gingivalis in human cells. J Immunol (2009) 182:2395-404. doi:10.4049/jimmunol.0800909

55. Abdul-Sater AA, Koo E, Häcker G, Ojcius DM. Inflammasome-dependent caspase-1 activation in cervical epithelial cells stimulates growth of the intracellular pathogen Chlamydia trachomatis. J Biol Chem (2009) 284:26789-96. doi:10.1074/jbc.M109.026823

56. He X, Mekasha S, Mavrogiorgos N. Inflammation and fibrosis during Chlamydia pneumoniae infection is regulated by IL-1 and the NLRP3/ASC inflammasome. J Immunol (2010) 184:5743-54. doi:10.4049/jimmunol.0903937

57. Thomas PG, Dash P, Aldridge JR Jr, Ellebedy AH. The intracellular sensor NLRP3 mediates key innate and healing responses to influenza A virus via the regulation of caspase-1. Immunity (2009) 30(4):566-75. doi:10.1016/j. immuni.2009.02.006

58. Allen IC, Scull MA, Moore CB, Holl EK. The NLRP3 inflammasome mediates in vivo innate immunity to influenza A virus through recognition of viral RNA. Immunity (2009) 30(4):556-65. doi:10.1016/j.immuni.2009.02.005

59. Saïd-Sadier N, Padilla E, Langsley G, Ojcius DM. Aspergillus fumigatus stimulates the NLRP3 inflammasome through a pathway requiring ROS production and the Syk tyrosine kinase. PLoS One (2010) 5:e10008. doi:10.1371/journal. pone. 0010008

60. Lima-Junior DS, Costa DL, Carregaro V, Cunha LD, Silva ALN, Mineo TWP, et al. Inflammasome-derived IL- $1 \beta$ production induces nitric oxide-mediated resistance to Leishmania. Nat Med (2013) 19:909-15. doi:10.1038/nm.3221

61. Zhou R, Yazdi AS, Menu P, Tschopp J. A role for mitochondria in NLRP3 inflammasome activation. Nature (2010) 469:221-5. doi:10.1038/nature09663

62. Franchi L, Amer A, Body-Malapel M, Kanneganti T-D, Özören N, Jagirdar $\mathrm{R}$, et al. Cytosolic flagellin requires Ipaf for activation of caspase- 1 and interleukin $1 \beta$ in Salmonella-infected macrophages. Nat Immunol (2006) 7:576-82. doi:10.1038/ni1346

63. Case CL, Shin S, Roy CR. Asc and Ipaf inflammasomes direct distinct pathways for caspase-1 activation in response to Legionella pneumophila. Infect Immun (2009) 77:1981-91. doi:10.1128/IAI.01382-08

64. Vinzing M, Eitel J, Lippmann J, Hocke AC, Zahlten J, Slevogt H, et al. NAIP and Ipaf control Legionella pneumophila replication in human cells. J Immunol (2008) 180:6808-15.

65. Coers J, Vance RE, Fontana MF, Dietrich WF. Restriction of Legionella pneumophila growth in macrophages requires the concerted action of cytokine and Naip5/Ipaf signalling pathways. Cell Microbiol (2007) 9:2344-57. doi:10.1111/ j.1462-5822.2007.00963.x

66. Mariathasan S, Newton K, Monack DM, Vucic D, French DM, Lee WP, et al. Differential activation of the inflammasome by caspase-1 adaptors ASC and Ipaf. Nature (2004) 430:213-8. doi:10.1038/nature02664

67. Broz P, Newton K, Lamkanfi M, Mariathasan S, Dixit VM, Monack DM. Redundant roles for inflammasome receptors NLRP3 and NLRC4 in host defense against Salmonella. J Exp Med (2010) 207:1745-55. doi:10.1084/jem.20100257

68. Miao EA, Mao DP, Yudkovsky N, Bonneau R, Lorang CG, Warren SE, et al. From the cover: innate immune detection of the type III secretion apparatus through the NLRC4 inflammasome. Proc Natl Acad Sci U S A (2010) 107:3076-80. doi:10.1073/pnas.0913087107

69. Suzuki T, Franchi L, Toma C, Ashida H, Ogawa M, Yoshikawa Y, et al. Differential regulation of caspase-1 activation, pyroptosis, and autophagy via Ipaf and ASC in Shigella-infected macrophages. PLoS Pathog (2007) 3:e111. doi:10.1371/journal.ppat.0030111

70. Cohen TS, Prince AS. Activation of inflammasome signaling mediates pathology of acute P. aeruginosa pneumonia. J Clin Invest (2013) 123:1630-7. doi:10.1172/JCI66142

71. Sutterwala FS, Mijares LA, Li L, Ogura Y, Kazmierczak BI, Flavell RA. Immune recognition of Pseudomonas aeruginosa mediated by the IPAF/NLRC4 inflammasome. J Exp Med (2007) 204:3235-45. doi:10.1084/jem.20071239

72. Franchi L, Stoolman J, Kanneganti T-D, Verma A, Ramphal R, Nuñez G. Critical role for Ipaf in Pseudomonas aeruginosa-induced caspase-1 activation. Eur J Immunol (2007) 37:3030-9. doi:10.1002/eji.200737532

73. Zamboni DS, Kobayashi KS, Kohlsdorf T, Ogura Y, Long EM, Vance RE, et al. The Bircle cytosolic pattern-recognition receptor contributes to the detection and control of Legionella pneumophila infection. Nat Immunol (2006) 7:318-25. doi:10.1038/ni1305 
74. Lightfield KL, Persson J, Trinidad NJ, Brubaker SW, Kofoed EM, Sauer J-D, et al. Differential requirements for NAIP5 in activation of the NLRC4 inflammasome. Infect Immun (2011) 79:1606-14. doi:10.1128/IAI.01187-10

75. Shaw MH, Reimer T, Sánchez-Valdepeñas C, Warner N, Kim Y-G, Fresno M, et al. T cell-intrinsic role of Nod2 in promoting type 1 immunity to Toxoplasma gondii. Nat Immunol (2009) 10:1267-74. doi:10.1038/ni.1816

76. Caetano BC, Biswas A, Lima DS, Benevides L, Mineo TWP, Horta CV, et al. Intrinsic expression of Nod2 in CD4+ T lymphocytes is not necessary for the development of cell-mediated immunity and host resistance to Toxoplasma gondii. Eur J Immunol (2011) 41:3627-31. doi:10.1002/eji.201141876

77. Hugot JP, Chamaillard M, Zouali H, Lesage S, Cezard JP, Belaiche J, et al. Association of NOD2 leucine-rich repeat variants with susceptibility to Crohn's disease. Nature (2001) 411:599-603. doi:10.1038/35079107

78. Barnich N, Aguirre JE, Reinecker H-C, Xavier R, Podolsky DK. Membrane recruitment of NOD2 in intestinal epithelial cells is essential for nuclear factor$\{$ kappa\}B activation in muramyl dipeptide recognition. J Cell Biol (2005) 170:21-6. doi:10.1083/jcb.200502153

79. Latz E, Xiao TS, Stutz A. Activation and regulation of the inflammasomes. Nat Rev Immunol (2013) 13:397-411. doi:10.1038/nri3452

80. Masters SL, Dunne A, Subramanian SL, Hull RL, Tannahill GM, Sharp FA, et al. Activation of the NLRP3 inflammasome by islet amyloid polypeptide provides a mechanism for enhanced IL-1 $\beta$ in type 2 diabetes. Nat Immunol (2010) 11:897-904. doi:10.1038/ni.1935

81. Hu Z, Yan C, Liu P, Huang Z, Ma R, Zhang C, et al. Crystal structure of NLRC4 reveals its autoinhibition mechanism. Science (2013) 341:172-5. doi:10.1126/science.1236381

82. Lage SL, Buzzo CL, Amaral EP, Matteucci KC, Massis LM, Icimoto MY, et al. Cytosolic flagellin-induced lysosomal pathway regulates inflammasomedependent and -independent macrophage responses. Proc Natl Acad Sci U S A (2013) 110:E3321-30. doi:10.1073/pnas.1305316110

83. Magalhaes JG, Sorbara MT, Girardin SE, Philpott DJ. What is new with nods? Curr Opin Immunol (2011) 23:29-34. doi:10.1016/j.coi.2010.12.003

84. Arnoult D, Soares F, Tattoli I, Castanier C, Philpott DJ, Girardin SE. An Nterminal addressing sequence targets NLRX1 to the mitochondrial matrix. J Cell Sci (2009) 122:3161-8. doi:10.1242/jcs.051193

85. Moore CB, Bergstralh DT, Duncan JA, Lei Y, Morrison TE, Zimmermann AG, et al. NLRX1 is a regulator of mitochondrial antiviral immunity. Nature (2008) 451:573-7. doi:10.1038/nature06501

86. Tattoli I, Sorbara MT, Vuckovic D, Ling A, Soares F, Carneiro LAM, et al. Amino acid starvation induced by invasive bacterial pathogens triggers an innate host defense program. Cell Host Microbe (2012) 11:563-75. doi:10.1016/j.chom. 2012.04.012

87. Eibl C, Grigoriu S, Hessenberger M, Wenger J, Puehringer S, Pinheiro AS, et al. Structural and functional analysis of the NLRP4 pyrin domain. Biochemistry (2012) 51:7330-41. doi:10.1021/bi3007059

88. Cui J, Li Y, Zhu L, Liu D, Songyang Z, Wang HY, et al. NLRP4 negatively regulates type I interferon signaling by targeting the kinase TBK1 for degradation via the ubiquitin ligase DTX4. Nat Immunol (2012) 13:387-95. doi:10.1038/ni.2239

89. Klionsky DJ. Autophagy: from phenomenology to molecular understanding in less than a decade. Nat Rev Mol Cell Biol (2007) 8:931-7. doi:10.1038/nrm2245

90. Yang Z, Klionsky DJ. Eaten alive: a history of macroautophagy. Nat Cell Biol (2010) 12:814-22. doi:10.1038/ncb0910-814

91. Choi AMK, Ryter SW, Levine B. Autophagy in human health and disease. NEngl J Med (2013) 368:651-62. doi:10.1056/NEJMra1205406

92. Hussey S, Travassos LH, Jones NL. Autophagy as an emerging dimension to adaptive and innate immunity. Semin Immunol (2009) 21:233-41. doi:10.1016/j.smim.2009.05.004

93. Mizushima N, Levine B, Cuervo AM, Klionsky DJ. Autophagy fights disease through cellular self-digestion. Nature (2008) 451:1069-75. doi:10.1038/ nature06639

94. Besteiro S, Brooks CF, Striepen B, Dubremetz JF. Autophagy protein Atg3 is essential for maintaining mitochondrial integrity and for normal intracellular development of Toxoplasma gondii tachyzoites. PLoS Pathog (2011) 7(12):e1002416. doi:10.1371/journal.ppat.1002416

95. Klionsky DJ, Abdalla FC, Abeliovich H, Abraham RT, Acevedo-Arozena A, Adeli $\mathrm{K}$, et al. Guidelines for the use and interpretation of assays for monitoring autophagy. Autophagy (2012) 8:445-544. doi:10.4161/auto.19926
96. Ragusa MJ, Stanley RE, Hurley JH. Architecture of the Atg17 complex as a scaffold for autophagosome biogenesis. Cell (2012) 151:1501-12. doi:10.1016/ j.cell.2012.11.028

97. Alers S, Löffler AS, Paasch F, Dieterle AM, Keppeler H, Lauber K, et al. Atg13 and FIP200 act independently of Ulk1 and Ulk2 in autophagy induction. Autophagy (2011) 7:1423-33. doi:10.4161/auto.7.12.18027

98. Chang T-K, Shravage BV, Hayes SD, Powers CM, Simin RT, Wade Harper J, et al. Ubal functions in Atg7- and Atg3-independent autophagy. Nat Cell Biol (2013) 15:1067-78. doi:10.1038/ncb2804

99. Nishida Y, Arakawa S, Fujitani K, Yamaguchi H, Mizuta T, Kanaseki T, et al. Discovery of Atg5/Atg7-independent alternative macroautophagy. Nature (2009) 461:654-8. doi:10.1038/nature08455

100. Kunz J, Henriquez R, Schneider U, Deuter-Reinhard M, Movva NR, Hall $\mathrm{MN}$. Target of rapamycin in yeast, TOR2, is an essential phosphatidylinositol kinase homolog required for G1 progression. Cell (1993) 73:585-96. doi:10.1016/0092-8674(93)90144-F

101. Schu PV, Takegawa K, Fry MJ, Stack JH, Waterfield MD, Emr SD. Phosphatidylinositol 3-kinase encoded by yeast VPS34 gene essential for protein sorting. Science (1993) 260:88-91. doi:10.1126/science.8385367

102. Brunn GJ, Williams J, Sabers C, Wiederrecht G, Lawrence JC, Abraham RT. Direct inhibition of the signaling functions of the mammalian target of rapamycin by the phosphoinositide 3-kinase inhibitors, wortmannin and LY294002. EMBO J (1996) 15:5256-67.

103. Fruman DA. Towards an understanding of isoform specificity in phosphoinositide 3-kinase signalling in lymphocytes. Biochem Soc Trans (2004) 32:315-9. doi:10.1042/BST0320315

104. Alessi DR, Andjelkovic M, Caudwell B, Cron P, Morrice N, Cohen P, et al. Mechanism of activation of protein kinase B by insulin and IGF-1. EMBO J (1996) 15:6541-51.

105. Díaz-Troya S, Pérez-Pérez ME, Florencio FJ, Crespo JL. The role of TOR in autophagy regulation from yeast to plants and mammals. Autophagy (2008) 4:851-65.

106. Hay N. Upstream and downstream of mTOR. Genes Dev (2004) 18:1926-45. doi:10.1101/gad.1212704

107. Takeuchi H, Kondo Y, Fujiwara K, Kanzawa T, Aoki H, Mills GB, et al. Synergistic augmentation of rapamycin-induced autophagy in malignant glioma cells by phosphatidylinositol 3-kinase/protein kinase B inhibitors. Cancer Res (2005) 65:3336-46. doi:10.1158/0008-5472.CAN-04-3640

108. Jung CH, Jun CB, Ro SH, Kim YM, Otto NM, Cao J, et al. ULK-Atg13-FIP200 complexes mediate mTOR signaling to the autophagy machinery. Mol Biol Cell (2009) 20:1992-2003. doi:10.1091/mbc.E08-12-1249

109. Kraft C, Kijanska M, Kalie E, Siergiejuk E, Lee SS, Semplicio G, et al. Binding of the Atg1/ULK1 kinase to the ubiquitin-like protein Atg8 regulates autophagy. EMBO J (2012) 31:3691-703. doi:10.1038/emboj.2012.225

110. Linares JF, Duran A, Yajima T, Pasparakis M, Moscat J, Diaz-Meco MT. K63 polyubiquitination and activation of mTOR by the p62-TRAF6 complex in nutrient-activated cells. Mol Cell (2013) 51:283-96. doi:10.1016/j.molcel.2013. 06.020

111. Lindmo K. Regulation of membrane traffic by phosphoinositide 3-kinases. J Cell Sci (2006) 119:605-14. doi:10.1242/jcs.02855

112. Petiot A, Ogier-Denis E, Blommaart EF, Meijer AJ, Codogno P. Distinct classes of phosphatidylinositol 3'-kinases are involved in signaling pathways that control macroautophagy in HT-29 cells. J Biol Chem (2000) 275:992-8. doi:10.1074/jbc.275.2.992

113. Cebollero E, van der Vaart A, Zhao M, Rieter E, Klionsky DJ, Helms JB, et al. Phosphatidylinositol-3-phosphate clearance plays a key role in autophagosome completion. Curr Biol (2012) 22:1545-53. doi:10.1016/j.cub.2012.06.029

114. Boya P, Reggiori F, Codogno P. Emerging regulation and functions of autophagy. Nat Cell Biol (2013) 15:713-20. doi:10.1038/ncb2788

115. Yuk JM, Yoshimori T, Jo E-K. Autophagy and bacterial infectious diseases. Exp Mol Med (2012) 44:99-108. doi:10.3858/emm.2012.44.2.032

116. Nakagawa I, Amano A, Mizushima N, Yamamoto A, Yamaguchi H, Kamimoto $\mathrm{T}$, et al. Autophagy defends cells against invading group A Streptococcus. Science (2004) 306:1037-40. doi:10.1126/science.1103966

117. Kayath CA, Hussey S, El hajjami N, Nagra K, Philpott D, Allaoui A. Escape of intracellular Shigella from autophagy requires binding to cholesterol through the type III effector, IcsB. Microbes Infect (2010) 12:956-66. doi:10.1016/j. micinf.2010.06.006 
118. Ogawa M, Yoshimori T, Suzuki T, Sagara H, Mizushima N, Sasakawa C. Escape of intracellular Shigella from autophagy. Science (2005) 307:727-31. doi:10.1126/science.1106036

119. Dupont N, Lacas-Gervais S, Bertout J, Paz I, Freche B, Van Nhieu GT, et al. Shigella phagocytic vacuolar membrane remnants participate in the cellular response to pathogen invasion and are regulated by autophagy. Cell Host Microbe (2009) 6:137-49. doi:10.1016/j.chom.2009.07.005

120. Cullinane M, Gong L, Li X, Lazar-Adler N, Tra T, Wolvetang E, et al. Stimulation of autophagy suppresses the intracellular survival of Burkholderia pseudomallei in mammalian cell lines. Autophagy (2008) 4:744-53.

121. Birmingham CL, Canadien V, Kaniuk NA, Steinberg BE, Higgins DE, Brumell JH. Listeriolysin O allows Listeria monocytogenes replication in macrophage vacuoles. Nature (2008) 451:350-4. doi:10.1038/nature06479

122. Birmingham CL. Autophagy controls Salmonella infection in response to damage to the Salmonella-containing vacuole. J Biol Chem (2006) 281:11374-83. doi:10.1074/jbc.M509157200

123. Gutierrez MG, Master SS, Singh SB, Taylor GA, Colombo MI, Deretic V. Autophagy is a defense mechanism inhibiting BCG and Mycobacterium tuberculosis survival in infected macrophages. Cell (2004) 119:1-14. doi:10.1016/j. cell.2004.11.038

124. Orvedahl A, Alexander D, Tallóczy Z, Sun Q, Wei Y, Zhang W, et al. HSV-1 ICP34.5 confers neurovirulence by targeting the Beclin 1 autophagy protein. Cell Host Microbe (2007) 1:23-35. doi:10.1016/j.chom.2006.12.001

125. Lee HK, Lund JM, Ramanathan B, Mizushima N, Iwasaki A. Autophagydependent viral recognition by plasmacytoid dendritic cells. Science (2007) 315:1398-401. doi:10.1126/science.1136880

126. Xu Y, Jagannath C, Liu X-D, Sharafkhaneh A, Kolodziejska KE, Eissa NT. Tolllike receptor 4 is a sensor for autophagy associated with innate immunity. Immunity (2007) 27:135-44. doi:10.1016/j.immuni.2007.05.022

127. Delgado MA, Elmaoued RA, Davis AS, Kyei G, Deretic V. Toll-like receptors control autophagy. EMBOJ (2008) 27:1110-21. doi:10.1038/emboj. 2008.31

128. Shi C-S, Kehrl JH. MyD88 and Trif target Beclin 1 to trigger autophagy in macrophages. J Biol Chem (2008) 283:33175-82. doi:10.1074/jbc.M804478200

129. Schmitz F, Heit A, Dreher S, Eisenächer K, Mages J, Haas T, et al. Mammalian target of rapamycin (mTOR) orchestrates the defense program of innate immune cells. Eur J Immunol (2008) 38:2981-92. doi:10.1002/eji.200838761

130. Yano T, Mita S, Ohmori H, Oshima Y, Fujimoto Y, Ueda R, et al. Autophagic control of listeria through intracellular innate immune recognition in Drosophila. Nat Immunol (2008) 9:908-16. doi:10.1038/ni.1634

131. Cooney R, Baker J, Brain O, Danis B, Pichulik T, Allan P, et al. NOD2 stimulation induces autophagy in dendritic cells influencing bacterial handling and antigen presentation. Nat Med (2009) 16:90-7. doi:10.1038/nm.2069

132. Travassos LH, Carneiro LAM, Ramjeet M, Hussey S, Kim Y-G, Magalhaes JG, et al. Nod1 and Nod2 direct autophagy by recruiting ATG16L1 to the plasma membrane at the site of bacterial entry. Nat Immunol (2010) 11:55-62. doi:10.1038/ni.1823

133. Rioux JD, Xavier RJ, Taylor KD, Silverberg MS, Goyette P, Huett A, et al. Genome-wide association study identifies new susceptibility loci for Crohn disease and implicates autophagy in disease pathogenesis. Nat Genet (2007) 39:596-604. doi:10.1038/ng2032

134. Kuballa P, Huett A, Rioux JD, Daly MJ, Xavier RJ. Impaired autophagy of an intracellular pathogen induced by a Crohn's disease associated ATG16L1 variant. PLoS One (2008) 3:e3391. doi:10.1371/journal.pone.0003391

135. Glubb DM, Gearry RB, Barclay ML, Roberts RL, Pearson J, Keenan JI, et al. NOD2 and ATG16L1 polymorphisms affect monocyte responses in Crohn's disease. World J Gastroenterol (2011) 17:2829-37. doi:10.3748/wjg.v17.i23. 2829

136. Plantinga TS, Joosten LA, Netea MG. ATG16L1 polymorphisms are associated with NOD2-induced hyperinflammation. Autophagy (2011) 7:1074-5. doi:10.4161/auto.7.9.15867

137. Kleinnijenhuis J, Oosting M, Plantinga TS, van der Meer JWM, Joosten LAB, Crevel RV, et al. Autophagy modulates the Mycobacterium tuberculosis-induced cytokine response. Immunology (2011) 134:341-8. doi:10.1111/j.1365-2567. 2011.03494.x

138. Byrne BG, Dubuisson JF, Joshi AD, Persson JJ, Swanson MS. Inflammasome components coordinate autophagy and pyroptosis as macrophage responses to infection. MBio (2012) 4:e620-612. doi:10.1128/mBio.00620-12
139. Lei Y, Wen H, Yu Y, Taxman DJ, Zhang L, Widman DG, et al. The mitochondrial proteins NLRX1 and TUFM form a complex that regulates Type I interferon and autophagy. Immunity (2012) 36:933-46. doi:10.1016/j.immuni.2012.03. 025

140. Shelly S, Lukinova N, Bambina S, Berman A, Cherry S. Autophagy is an essential component of Drosophila immunity against vesicular stomatitis virus. Immunity (2009) 30:588-98. doi:10.1016/j.immuni.2009.02.009

141. Soares F, Tattoli I, Wortzman ME, Arnoult D, Philpott DJ, Girardin SE. NLRX1 does not inhibit MAVS-dependent antiviral signalling. Innate Immun (2012) 19(4):438-48. doi:10.1177/1753425912467383

142. Rebsamen M, Vazquez J, Tardivel A, Guarda G, Curran J, Tschopp J. NLRX1/NOD5 deficiency does not affect MAVS signalling. Cell Death Differ (2011) 18:1387-1387. doi:10.1038/cdd.2011.64

143. Allen IC, Wilson JE, Schneider M, Lich JD, Roberts RA, Arthur JC, et al. NLRP12 suppresses colon inflammation and tumorigenesis through the negative regulation of noncanonical NF-кB signaling. Immunity (2012) 36:742-54 doi:10.1016/j.immuni.2012.03.012

144. Jounai N, Kobiyama K, Shiina M, Ogata K, Ishii KJ, Takeshita F. NLRP4 negatively regulates autophagic processes through an association with Beclin1. J Immunol (2011) 186:1646-55. doi:10.4049/jimmunol.1001654

145. Levine B, Mizushima N, Virgin HW. Autophagy in immunity and inflammation. Nature (2011) 469:323-35. doi:10.1038/nature09782

146. Jounai N, Takeshita F, Kobiyama K, Sawano A, Miyawaki A, Xin KQ, et al. The Atg5 Atg12 conjugate associates with innate antiviral immune responses. Proc Natl Acad Sci U S A (2007) 104:14050-5. doi:10.1073/pnas.0704014104

147. Tal MC, Sasai M, Lee HK, Yordy B, Shadel GS, Iwasaki A. Absence of autophagy results in reactive oxygen species-dependent amplification of RLR signaling. Proc Natl Acad Sci U S A (2009) 106:2770-5. doi:10.1073/pnas.0807694106

148. Lupfer C, Thomas PG, Anand PK, Vogel P, Milasta S, Martinez J, et al. Receptor interacting protein kinase 2-mediated mitophagy regulates inflammasome activation during virus infection. Nat Immunol (2013) 14:480-8. doi:10.1038/ni.2563

149. Harris J, Hartman M, Roche C, Zeng SG, O'Shea A, Sharp FA, et al. Autophagy controls IL-1 secretion by targeting pro-IL-1 for degradation. J Biol Chem (2011) 286:9587-97. doi:10.1074/jbc.M110.202911

150. Saitoh T, Fujita N, Jang MH, Uematsu S, Yang B-G, Satoh T, et al. Loss of the autophagy protein Atg16L1 enhances endotoxin-induced IL-1 $\beta$ production. Nature (2008) 456:264-8. doi:10.1038/nature07383

151. Shi C-S, Shenderov K, Huang N-N, Kabat J, Abu-Asab M, Fitzgerald KA, et al. Activation of autophagy by inflammatory signals limits IL- $1 \beta$ production by targeting ubiquitinated inflammasomes for destruction. Nat Immunol (2012) 13:255-63. doi:10.1038/ni.2215

152. Bauernfeind F, Bartok E, Rieger A, Franchi L, Nuñez G, Hornung V. Cutting edge: reactive oxygen species inhibitors block priming, but not activation, of the NLRP3 inflammasome. J Immunol (2011) 187:613-7. doi:10.4049/jimmunol. 1100613

153. Dostert C, Pétrilli V, van Bruggen R, Steele C, Mossman BT, Tschopp J. Innate immune activation through Nalp3 inflammasome sensing of asbestos and silica. Science (2008) 320:674-7. doi:10.1126/science.1156995

154. Latz E. NOX-free inflammasome activation. Blood (2010) 116:1393-4. doi:10. 1182/blood-2010-06-287342

155. Meissner F, Seger RA, Moshous D, Fischer A, Reichenbach J, Zychlinsky A. Inflammasome activation in NADPH oxidase defective mononuclear phagocytes from patients with chronic granulomatous disease. Blood (2010) 116:1570-3. doi:10.1182/blood-2010-01-264218

156. Davis BK, Wen H, Ting JP. The inflammasome NLRs in immunity, inflammation, and associated diseases. Annu Rev Immunol (2011) 29:707-35. doi:10. 1146/annurev-immunol-031210-101405

157. Dupont N, Jiang S, Pilli M, Ornatowski W, Bhattacharya D, Deretic V. Autophagy-based unconventional secretory pathway for extracellular delivery of IL-1 $\beta$. EMBO J (2011) 30:4701-11. doi:10.1038/emboj.2011.398

158. Juliana C, Fernandes-Alnemri T, Kang S, Farias A, Qin F, Alnemri ES. Non-transcriptional priming and deubiquitination regulate NLRP3 inflammasome activation. J Biol Chem (2012) 287:36617-22. doi:10.1074/jbc.M112. 407130

159. Girardin SE, Travassos LH, Hervé M, Blanot D, Boneca IG, Philpott DJ, et al. Peptidoglycan molecular requirements allowing detection by Nod1 and Nod2. J Biol Chem (2003) 278:41702-8. doi:10.1074/jbc.M307198200 
Conflict of Interest Statement: The authors declare that the research was conducted in the absence of any commercial or financial relationships that could be construed as a potential conflict of interest.

Received: 31 July 2013; accepted: 24 October 2013; published online: 11 November 2013.

Citation: Carneiro LAM and Travassos LH (2013) The interplay between NLRs and autophagy in immunity and inflammation. Front. Immunol. 4:361. doi:10.3389/ fimmu.2013.00361
This article was submitted to Molecular Innate Immunity, a section of the journal Frontiers in Immunology.

Copyright (c) 2013 Carneiro and Travassos. This is an open-access article distributed under the terms of the Creative Commons Attribution License (CC $B Y)$. The use, distribution or reproduction in other forums is permitted, provided the original author(s) or licensor are credited and that the original publication in this journal is cited, in accordance with accepted academic practice. No use, distribution or reproduction is permitted which does not comply with these terms. 